\title{
16. STRATIGRAPHIC PALYNOLOGY OF SELECTED MESOZOIC SAMPLES, DSDP HOLE 327A AND SITE 330
}

\author{
Richard W. Hedlund and Dan Beju, Amoco Production Company Research Center, Tulsa, Oklahoma
}

\section{INTRODUCTION}

This paper presents the results of palynologic analyses of 13 selected samples from the sedimentary sequences cored at Hole 327A and Site 330 from Leg 36 of the Deep Sea Drilling Project (Figure 1). Core samples were analyzed from the following depths:

Hole $327 \mathrm{~A}$, at $341,368,396,426,453$, and 463 meters Site 330 , at $271-281,315,317-318.5,352,377.5-379$, 440 , and 525 meters.

The six samples from Hole 327A and the upper five samples from Site 330 are within a sapropelic claystone sequence. The lower two samples from Site 330 are within an interbedded sandstone, clayey siltstone, and limestone sequence containing plant debris (Barker et al., 1974).

All samples yielded well-preserved palynomorph assemblages consisting of terrestrial spores and pollen grains, tasmanitids, and marine dinoflagellate cysts. The samples were prepared by pretreatment with dilute hydrochloric acid, followed by hydrofluoric acid digestion. No oxidation was necessary before strewmounting the residues.

The distribution and relative frequencies of species are summarized in Figure 2 and are listed below. Selected species are illustrated in Plates 1 to 3 . The spores and pollen are broadly classified in alphabetical order according to the system proposed by Potonié (1956, 1958, 1960) and modified by Dettmann (1963).

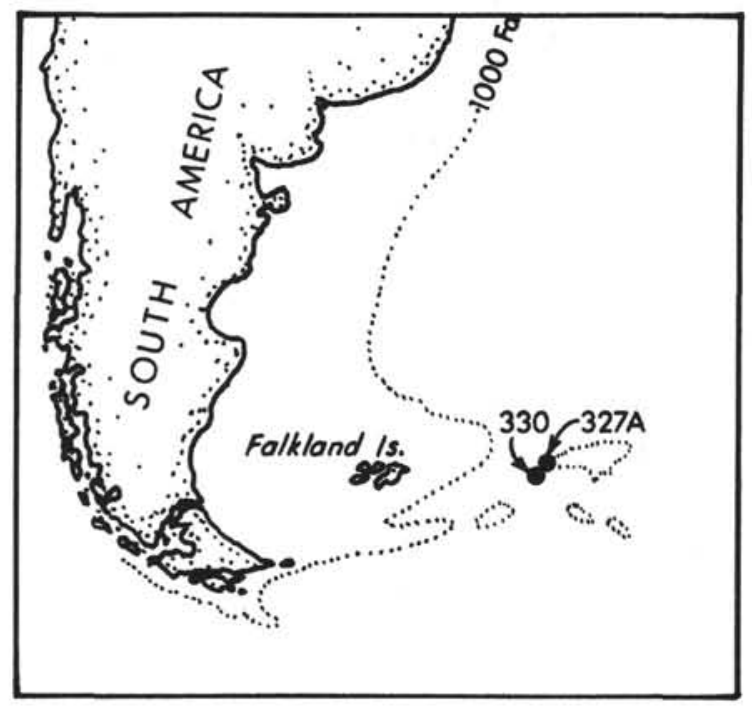

Figure 1. Sample location map, Sites $327 A$ and 330.
Dinoflagellate cysts are listed with reference to two orders of presumed affinities: species within the Order Peridiniales are listed alphabetically. Slides and residues are housed in the Palynologic Collection of Amoco Production Company Research Center, Tulsa, Oklahoma. Examination and photography of specimens were with a Zeiss Universal microscope equipped with phase contrast and Nomarski differential interference contrast in the above institution.

\section{TAXONOMIC LIST}

$\begin{aligned} \text { Anteturma } & \text { SPORITES } \\ \text { Turma } & \text { TRILETES } \\ \text { Suprasubturma } & \text { ACAVATITRILETES } \\ \text { Subturma } & \text { AZONOTRILETES }\end{aligned}$

Baculatisporites comaumensis (Cookson) Potonié, 1956

Ceratosporites equalis Cookson and Dettmann, 1958; Plate 1, Figure 5

Cicatricosisporites hallei Delcourt and Sprumont, 1955; Plate 1, Figure 7

Cicatricosisporites sp.; Plate 1, Figure 6

Concavisporites jurienensis Balme, 1957

Cyathidites australis Couper, 1953

Cyathidites minor Couper, 1953

Dictyophyllidites $\mathrm{sp}$.

Ischyosporites crateris Balme, 1957; Plate 1, Figure 17

Lycopodiumsporites austroclavatidites (Cookson) Potonié, 1956

Neoraistrickia sp.

Rubinella major (Couper) Norris, 1969

Rubinella sp.; Plate 1, Figure 12

Todisporites minor Couper, 1958

Verrucosisporites $\mathrm{sp}$.

\section{Subturma ZONOTRILETES}

Cingulatisporites sp.; Plate 1, Figure 10

Clavifera triplex (Bolchovitina) Bolchovitina, 1968; Plate 1, Figure 4 Contignisporites glebulentus Dettmann, 1963; Plate 1, Figure 14

Coronatispora valdensis (Couper) Dettmann, 1963; Plate 1, Figure 13

Foraminisporis wonthaggiensis (Cookson and Dettmann) Dettmann, 1963

Gleicheniidites confossus Hedlund, 1966; Plate 1, Figure 3

Gleicheniidites senonicus Ross, 1949; Plate 1, Figure 1

Gleicheniidites sp.; Plate 1, Figure 2

Matonisporites crassiangulatus (Balme) Levet-Carette, 1964; Plate 1, Figure 16

Trilobosporites spp.

$$
\text { Suprasubturma PERINOTRILETES }
$$

Densoisporites velatus Weyland and Krieger, emend. Krasnova, 1961 Heliosporites sp.; Plate 1, Figure 8

$$
\text { Turma HILATES }
$$

Coptospora sp.; Plate 1, Figure 11

$$
\begin{gathered}
\text { Anteturma POLLENITES } \\
\text { Turma SACCITES } \\
\text { Subturma MONOSACCITES }
\end{gathered}
$$

Cerebropollenites mesozoicus (Couper) Nilsson, 1958 

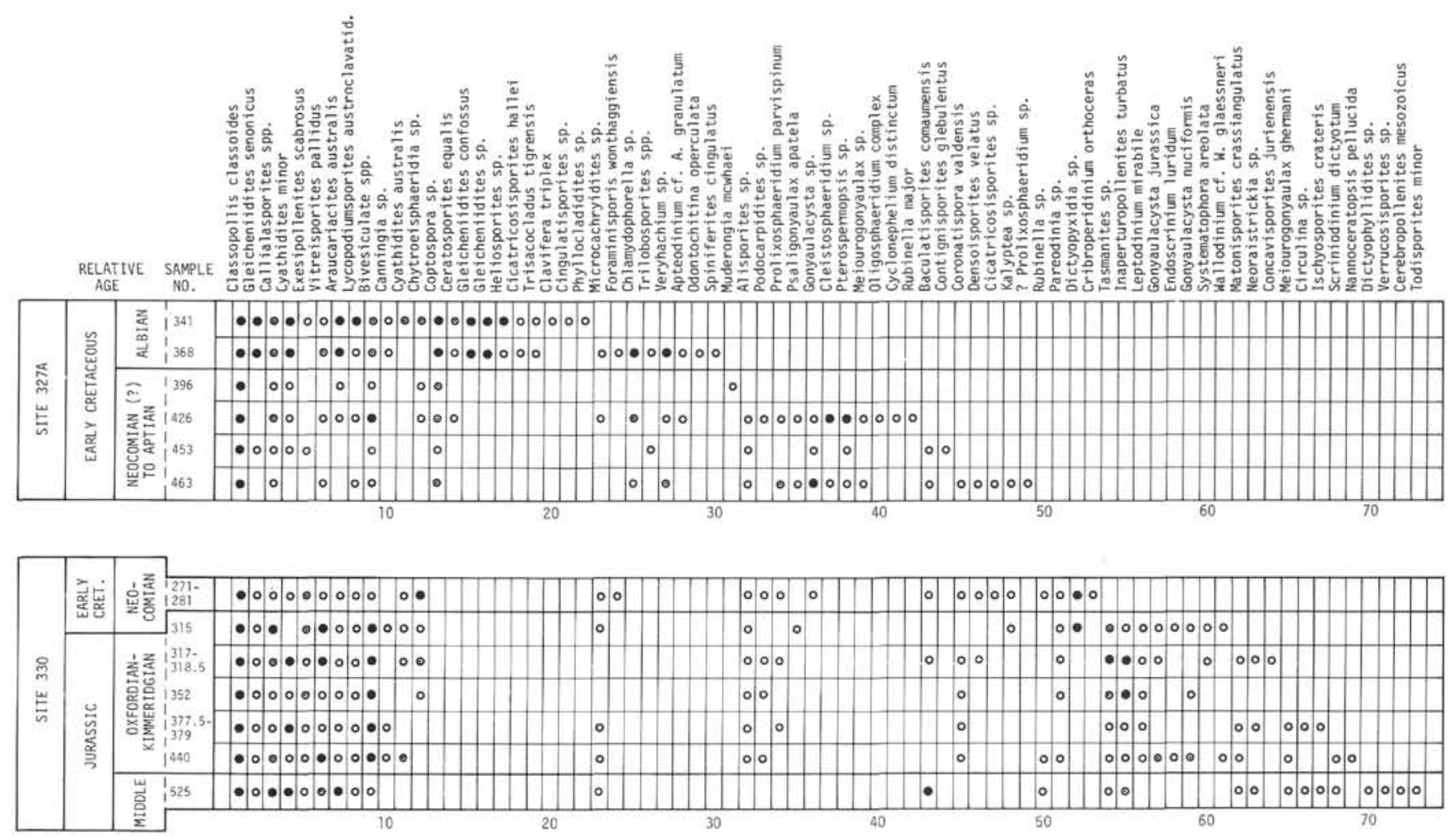

LEGEND

- comon to abundant

- occastonal

- RARE

Figure 2. Distribution and relative frequencies of palynomorph species.

Subturma DISACCITES

Alisporites sp.; Plate 1, Figure 19

Microcachryidites sp.; Plate 1, Figure 20

Phyllocladidites sp.

Podocarpidites sp.; Plate 1, Figure 21

Vitreisporites pallidus (Reissinger) Potonié, 1960

\section{Subturma POLYSACCITES}

Callialasporites spp. includes

C. dampieri (Balme) Dev, 1961

C. trilobatus (Balme) Dev, 1961

Trisacocladus tigrensis Archangelsky, 1965; Plate 1, Figure 15

\section{Turma ALETES}

Araucariacites australis Cookson, 1947

Inaperturopollenites turbatus Balme, 1957; Plate 1, Figure 18

\section{Turma POROSES}

Exesipollenites scabrosus Norris, 1969; Plate 1, Figure 9

\section{MIOSPORES INCERTAE SEDIS}

Circulina sp.

Classopollis classoides Pflug, emend. Pocock and Jansonius, 1961

\section{Class DINOPHYCEAE}

\section{Order DINOPHYSIDALES}

Nannoceratopsis pellucida Deflandre, emend. Evitt, 1961; Plate 3, Figure 6

\section{Order PERIDINIALES}

Apteodinium cf. A. granulatum Eisenack, 1958; Plate 2, Figure 4 Canningia sp.

Chlamydophorella sp.
Chytroeisphaeridia sp.

Cleistosphaeridium sp.; Plate 2, Figure 8

Cribroperidinium orthoceras (Eisenack) Davey, 1969; Plate 2, Figure 11

Cyclonephelium distinctum Deflandre and Cookson, 1955; Plate 2, Figure 10

Dictyopyxidia sp.

Endoscrinium luridum (Deflandre) Gocht, 1970; Plate 3, Figure 4 Gonyaulacysta jurassica (Deflandre) Norris and Sarjeant, 1965; Plate 3, Figure 1

Gonyaulacysta nuciformis (Deflandre) Sarjeant, 1968; Plate 3, Figure 8

Gonyaulacysta sp.; Plate 2, Figures 1, 2

Kalyptea sp.

Leptodinium mirabile Klement, 1960; Plate 3, Figures 2, 3

Meiourogonyaulax ghermani Beju, 1971; Plate 3, Figure 5

Meiourogonyaulax sp.; Plate 2, Figure 6

Muderongia mcwhaei Cookson and Eisenack, 1958; Plate 2, Figure 9

Odontochitina operculata (Wetzel) Deflandre and Cookson, 1955

Oligosphaeridium complex (White) Davey and Williams, 1966; Plate 2 , Figure 13

Pareodinia sp.; Plate 3, Figure 11

Prolixosphaeridium parvispinum (Deflandre) Davey et al., 1969; Plate 2, Figure 7

?Prolixosphaeridium sp.; Plate 2, Figure 3

Psaligonyaulax apatela (Cookson and Eisenack) Sarjeant, 1969; Plate 2, Figure 5

Scriniodinium dictyotum Cookson and Eisenack, 1960; Plate 3, Figure 12

Spiniferites cingulatus (Wetzel) Sarjeant, 1970; Plate 2, Figure 12 Systematophora areolata Klement, 1960; Plate 3, Figures 9, 10

\section{INCERTAE SEDIS and ACRITARCHS}

Wallodinium cf. W. glaessneri (Cookson and Eisenack) Loeblich and Loeblich, 1968; Plate 3, Figure 7 
Pterospermopsis sp.

Tasmanites sp.; Plate 3, Figures 13, 14

Veryhachium sp.

\section{RESULTS}

Figure 2 illustrates the distribution and relative frequencies of species in analyzed samples from Hole 327A and Site 330. Samples are listed as "meters below sea bottom" for each site and are not plotted to scale. The vertical relationships between the two sections are diagrammatic and do not indicate precise stratigraphic relationships. However, palynologic data suggest that the sample at $271-281$ meters at Site 330 is somewhat older than the sample at 463 meters in Hole 327A.

\section{Hole 327A}

The sequence in Hole 327A consists of sediments ranging in age from Early Cretaceous to Recent. Only six samples from the Early Cretaceous sapropelic claystone were provided for this study ( 341 to $463 \mathrm{~m}$ ).

\section{1 to 368 meters}

Samples from this interval are dated as Albian in age on the basis of palynologic comparisons with subsurface studies in the Austral Basin of Santa Cruz Province, Argentina (Hedlund, unpublished manuscript). The assemblage consists mainly of terrestrial palynomorphs, with rarely occurring dinoflagellate cysts. The following species are the more significant:

Classopollis classoides Pflug, emend. Pocock and Jansonius, 1961

Gleicheniidites senonicus Ross, 1949

Exesipollenites scabrosus Norris, 1969

Canningia sp.

Coptospora sp.

Gleicheniidites confossus Hedlund, 1966

Gleicheniidites sp.

Trisacocladus tigrensis Archangelsky, 1965

Cingulatisporites $\mathrm{sp}$.

Cyathidites minor Couper, 1953

Heliosporites $\mathrm{sp}$.

Chlamydophorella $\mathrm{sp}$.

In addition, the sample at 368 meters contains Spiniferites cingulatus (Wetzel) Sarjeant, 1970, reported to occur in sediments no older than Albian in age (Millioud et al., 1975).

\section{6 to $463 \mathrm{~m}$}

This interval contains both terrestrial and marine palynomorphs and is dated as Neocomian (?) to Aptian in age. The sample at 396 meters contains specimens of Muderongia mcwhaei Cookson and Eisenack, 1958, a dinoflagellate cyst presently known to range from the Neocomian through Aptian in Australasia (Harker and Sarjeant, 1975). Samples at 426, 453, and 463 meters yielded the following species:

Prolixosphaeridium parvispinum (Deflandre) Davey et al., 1969

Psaligonyaulax apatela (Cookson and Eisenack) Sarjeant, 1969

Oligosphaeridium complex (White) Davey and Williams, 1966

Cyclonephelium distinctum Deflandre and Cookson, 1955
Gonyaulacysta sp.

Kalyptea sp.

Cicatricosisporites $\mathrm{sp}$.

Rubinella major (Couper) Norris, 1969

Contignisporites glebulentus Dettmann, 1963

Coronatispora valdensis (Couper) Dettmann, 1963

Densoisporites velatus Weyland and Krieger, emend.

Krasnova, 1961

Prolixosphaeridium parvispinum and Psaligonyaulax apatela are known to range from the Late Jurassic to the Early Cretaceous (Sarjeant, 1975). O. complex and $C$. distinctum have not been reported from sediments older than Valanginian in age (Millioud et al., 1975).

\section{SITE 330}

The analyzed sequence at Site 330 ranges in age from Middle Jurassic to Neocomian. Seven samples were provided from this sequence. The upper five samples are from the sapropelic claystone, and the lower two are within the interbedded sandstone, clayey siltstone, and limestone sequence (Barker et al., 1974).

\section{1 to $281 \mathrm{~m}$}

This interval contains both terrestrial and marine palynomorph species recovered from the lowest level $(463 \mathrm{~m})$ in Hole 327A. Specimens referred to Cribroperidinium orthoceras (Eisenack) Davey, 1969 also were found at this level. The occurrence of these taxa indicates a Neocomian age for the level, but lack of more numerous diagnostic species precludes a more precise age assignment.

\section{5 to $440 \mathrm{~m}$}

Samples within this interval yielded high relative abundances of bivesiculate pollen grains, tasmanitids, and dinoflagellate cysts. The more stratigrapically significant species include the following:

Systematophora areolata Klement, 1960

Gonyaulacysta jurassica (Deflandre) Norris and Sarjeant, 1965

Gonyaulacysta nuciformis (Deflandre) Sarjeant, 1968

Leptodinium mirabile Klement, 1960

Meiourogonyaulax ghermani Beju, 1971

Scriniodinium dictyotum Cookson and Eisenack, 1960

Endoscrinium luridum (Deflandre) Gocht, 1970

Wallodinium glaessneri (Cookson and Eisenack) Loeblich and Loeblich, 1968

Nannoceratopsis pellucida Deflandre, emend. Evitt, 1961

Most of these species have a cosmopolitan geographic distribution in Late Jurassic sediments (Norris, 1975). Their occurrences have been reported from numerous areas of both northern and southern hemispheres and indicate an Oxfordian-Kimmeridgian age (Sarjeant, 1975). Of the dinoflagellate cyst species recovered from the highest samples in this interval (315 m, Figure 2), S. areolata, G. jurassica, G. nuciformis, and $E$. luridum are not known to occur in sediments younger than Kimmeridgian (Sarjeant, 1975). This indicates a probable hiatus representing Portlandian (and possibly a portion of Neocomian) time between samples at 271-281 meters and 315 meters. A slight change 
in the flora is marked by the highest occurrences of $N$. pellucida and $S$. dictyotum at 440 meters, and the lowest occurrences of $S$. areolata, Kalyptea sp., and Dictyopyxidia sp. at 315 to 318.5 meters, suggesting a gradual Oxfordian-Kimmeridgian transition. A somewhat similar distribution of dinoflagellate cysts has been reported by Cookson and Eisenack $(1958,1960)$ from the Late Jurassic of Australia and New Guinea.

\section{$525 \mathrm{~m}$}

The lowest stratigraphic sample contains a rich but relatively undiversified assemblage of land-derived palynomorphs that are known to have long stratigraphic ranges in upper Mesozoic sediments. However, the abundant occurrences of Callialasporites dampieri (Balme) Dev, 1961; C. trilobatus (Balme) Dev, 1961 (both included as C. spp. on Figure 2); and Inaperturopollenites turbatus Balme, 1957, together with the accessory species Todisporites minor Couper, 1958; Ischyosporites crateris Balme, 1957; Baculatisporites comaumensis (Cookson) Potonié, 1956; and Cerebropollenites mesozoicus (Couper) Nilsson, 1958 suggest a Middle Jurassic age for this sample. In the southern hemisphere this assemblage compares closely with Middle Jurassic microfloras previously reported from Argentina (Menendez, 1968; Volkheimer, 1969, 1971, 1972, 1973), Madagascar (de Jekhowsky and Goubin, 1964; Goubin, 1965), and Australia (Balme, 1957, 1964). In these areas the "Dampieri Assemblage" of Balme (1964) occurs in abundance in the Middle Jurassic, while the Early Jurassic is characterized by taxa that are absent from the Hole 330 assemblage.

\section{CONCLUSIONS}

Sedimentary sequences from Hole 327A and Site 330 have been palynologically dated as Middle Jurassic to Albian. Middle Jurassic sediments are dominated by land-derived palynomorphs, while OxfordianKimmeridgian samples represent a shallow marine environment. A hiatus representing the Portlandian (and possibly a portion of the Neocomian) is indicated by the ranges of palynomorph taxa. Neocomian-Aptian sediments contain both terrestrial and marine fossils, but the Albian portion of Hole $327 \mathrm{~A}$ is predominantly a terrestrial assemblage.

\section{ADDENDUM}

After completing this manuscript, the authors became aware of a recent reevaluation of the genus Meiourogonyaulax Sargeant, 1966, which is now regarded as a junior synonym of Lithodinia Eisenack, 1935 (Gocht, 1975). Therefore, forms referred to Meiourogonyaulax ghermani Beju, 1971 and $M$. sp. in this paper should be transferred to Lithodinia.

\section{REFERENCES}

Balme, B.E., 1957. Spores and pollen grains from the Mesozoic of Western Australia: Commonwealth of Australia, C.S.I.R.O., 48 p. 1964. The palynological record of Australian preTertiary floras. In Cranwell, L.M. (Ed.), Ancient Pacific floras: Hawaii (Univ. Hawaii Press), p. 49-80.
Barker, P.F. et al., 1974. Southwestern Atlantic: Geotimes, v. 19 , p. $16-18$.

Cookson, I.C. and Eisenack, A., 1958. Microplankton from Australian and New Guinea Upper Mesozoic sediments: Roy. Soc. Victoria Proc., v. 70, p. 19-79.

, 1960. Upper Mesozoic microplankton from Australia and New Guinea: Paleontology, v. 2, p. 243261.

de Jekhowsky, B. and Goubin, N., 1964. Subsurface palynology in Madagascar: A stratigraphic sketch of the Permian, Triassic, and Jurassic of the Morondava Basin. In Cross, A.T. (Ed.), Palynology in oil exploration. a symposium: Soc. Econ. Paleont. Mineral., Spec. Publ. 11, p. 116-130.

Dettmann, M.E., 1963. Upper Mesozoic microfloras from southeastern Australia: Roy. Soc. Victoria, Proc., v. 77, p. 1-148.

Gocht, H., 1975. Morphologie und Wandstruktur von Lithodinia jurassica Eisenack 1935 (Dinoflagellata, Oberjura): N. Jb. Geol. Paläont. Mh., H.6, p. 343-359.

Goubin, N., 1965. Description et répartition des principaux Pollenites permiens, triasiques et jurassiques des sondages du bassin de Morondava (Madagascar): Rev. Inst. fr. Pétrole, v. 20, p. 1415-1461.

Harker, S.D. and Sarjeant, W.A.S., 1975. The stratigraphic distribution of organic-walled dinoflagellate cysts in the Cretaceous and Tertiary: Rev. Palaeobot. Palyn., v. 20, p. 217-315.

Menendez, C.A., 1968. Estudio palinologico del Jurasico Medio de Picún Leufú, Neuquén: Ameghiniana, v. 5, p. $379-405$.

Milloud, M.E., Williams, G.L., and Lentin, J.K., 1975. Stratigraphic range charts: Selected Cretaceous dinoflagellates. In Evitt, W.R. (Ed.), Forum on dinoflagellates held at Anaheim, California, 1973 Proc.: Am. Assoc. Strat. Palynol., Contrib. Ser. 4, p. 65-71.

Norris, G., 1975. Provincialism of Callovian-Neocomian dinoflagellate cysts in the northern and southern hemispheres. In Evitt, W.R. (Ed.), Forum on dinoflagellates held at Anaheim, California, 1973 Proc.: Am. Assoc. Strat. Palynol., Contrib. Ser. 4, p. 29-35.

Potonié, R., 1956. Synopsis der Gattungen der Sporae dispersae. I Teil, Sporites: Beih. Geol. Jb., v. 23, p. 1-103.

1958. Synopsis der Gattungen der Sporae dispersae. II Teil, Saccites, Aletes, Praecolpates, Polyplicates, Monocolpates: Beih. Geol. Jb., v. 31, p. 1-114. 1960. Synopsis der Gattungen der Sporae dispersae. III Teil, Nachträge Sporites, Fortsetzung Pollenites mit General-register zu Teil I-III: Beih. Geol. Jb., v. 39, p. 1189.

Sarjeant, W.A.S., 1975. Stratigraphic range charts: Triassic and Jurassic dinoflagellates. In Evitt, W.R. (Ed.), Forum on dinoflagellates held at Anaheim, California, 1973 Proc.: Am. Assoc. Strat. Palynol., Contrib. Ser. 4, p. 51-63.

Volkheimer, W., 1969. Esporas y granos de polen del Jurasico de Neuquén (Republica Argentina) II. Asociaciones microfloristicas, aspectos paleoecologicos y paleoclima: Ameghiniana, v. 6, p. 127-145.

1971. Algunos adelantos en la microbioestratigrafia del Jurasico en la Argentina y comparacion con otras regiones del Hemisferio Austral: Ameghiniana, v. 8, p. $341-355$.

1972. Estudio palinologico de un carbon Calloviano de Neuquén y consideraciones sobre los paleoclimas Jurasicos de la Argentina: Rev. Museo La Plata, v. 6 , p. 101-157.

1973. Palinologia estratigrafica del Jurasico de la Sierra de Chacai co y adyaciencias (Cuenca Neuquena, Republica Argentina) I: Ameghiniana, v. 10, p. 105-131. 



\section{PLATE 1}

Figure $1 \quad$ Gleicheniidites senonicus Ross, 1949. Hole 327A (341 m), $\times$ ca. 1000.

Figure 2 Gleicheniidites $\mathrm{sp}$. Hole $327 \mathrm{~A}(341 \mathrm{~m}), \times$ ca. 1000.

Figure 3 Gleicheniidites confossus Hedlund, 1966. Hole 327A (341 m), $\times$ ca. 1000.

Figure 4 Clavifera triplex (Bolchovitina) Bolchovitina, 1968.

Hole 327A (341 m), $\times$ ca. 1000.

Figure 5 Ceratosporites equalis Cookson and Dettmann, 1958.

Hole 327A (341 m), $\times$ ca. 1000.

Figure $6 \quad$ Cicatricosisporites $\mathrm{sp}$.

Hole $327 \mathrm{~A}(463 \mathrm{~m}), \times$ ca. 1000.

Figure $7 \quad$ Cicatricosisporites hallei Delcourt and Sprumont, 1955.

Hole 327 A $(368 \mathrm{~m}), \times$ ca. 1000 .

Figure 8 Heliosporites $\mathrm{sp}$.

Hole 327A (341 m), $\times$ ca. 1000.

Figure $9 \quad$ Exesipollenites scabrosus Norris, 1969.

Site $330(317 \mathrm{~m}), \times$ ca. 1000 .

Figure $10 \quad$ Cingulatisporites $\mathrm{sp}$.

Hole $327 \mathrm{~A}(463 \mathrm{~m}), \times$ ca. 650.

Figure $11 \quad$ Coptospora $\mathrm{sp}$.

Hole 327A $(341 \mathrm{~m}), \times$ ca. 1000.

Figure 12 Rubinella sp.

Site $330(440 \mathrm{~m}), \times$ ca. 650 .

Figure 13 Coronatispora valdensis (Couper) Dettmann, 1963. Site $330(317 \mathrm{~m}), \times$ ca. 1000 .

Figure 14 Contignisporites glebulentus Dettmann, 1963.

Hole 327A $(463 \mathrm{~m}), \times$ ca. 650 .

Figure 15 Trisacocladus tigrensis Archangelsky, 1965.

Hole 327A (368 m), $\times$ ca. 1000.

Figure 16 Matonisporites crassiangulatus (Balme) LevetCarette, 1964.

Site $330(525 \mathrm{~m}), \times$ ca. 650 .

Figure 17 Ischyosporites crateris Balme, 1957.

Site $330(525 \mathrm{~m}), \times$ ca. 1000 .

Figure $18 \quad$ Inaperturopollenites turbatus Balme, 1957.

Site $330(525 \mathrm{~m}), \times$ ca. 400 .

Figure $19 \quad$ Alisporites sp.

Site $330(440 \mathrm{~m}), \times$ ca. 650 .

Figure $20 \quad$ Microcachryidites sp.

Site $330(440 \mathrm{~m}), \times$ ca. 650 .

Figure $21 \quad$ Podocarpidites $\mathrm{sp}$.

Site $330(440 \mathrm{~m}), \times$ ca. 650 . 
PLATE 1

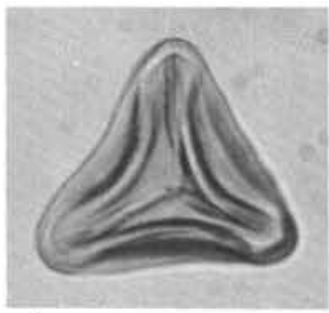

1

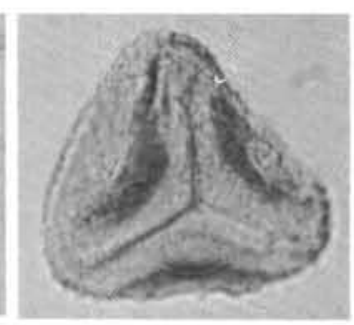

2

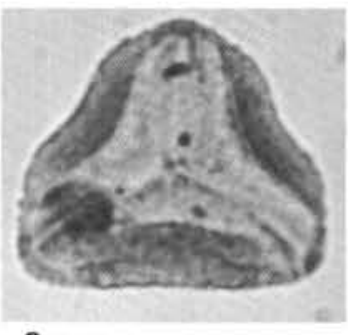

3

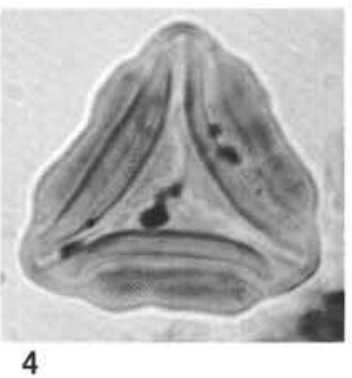

4
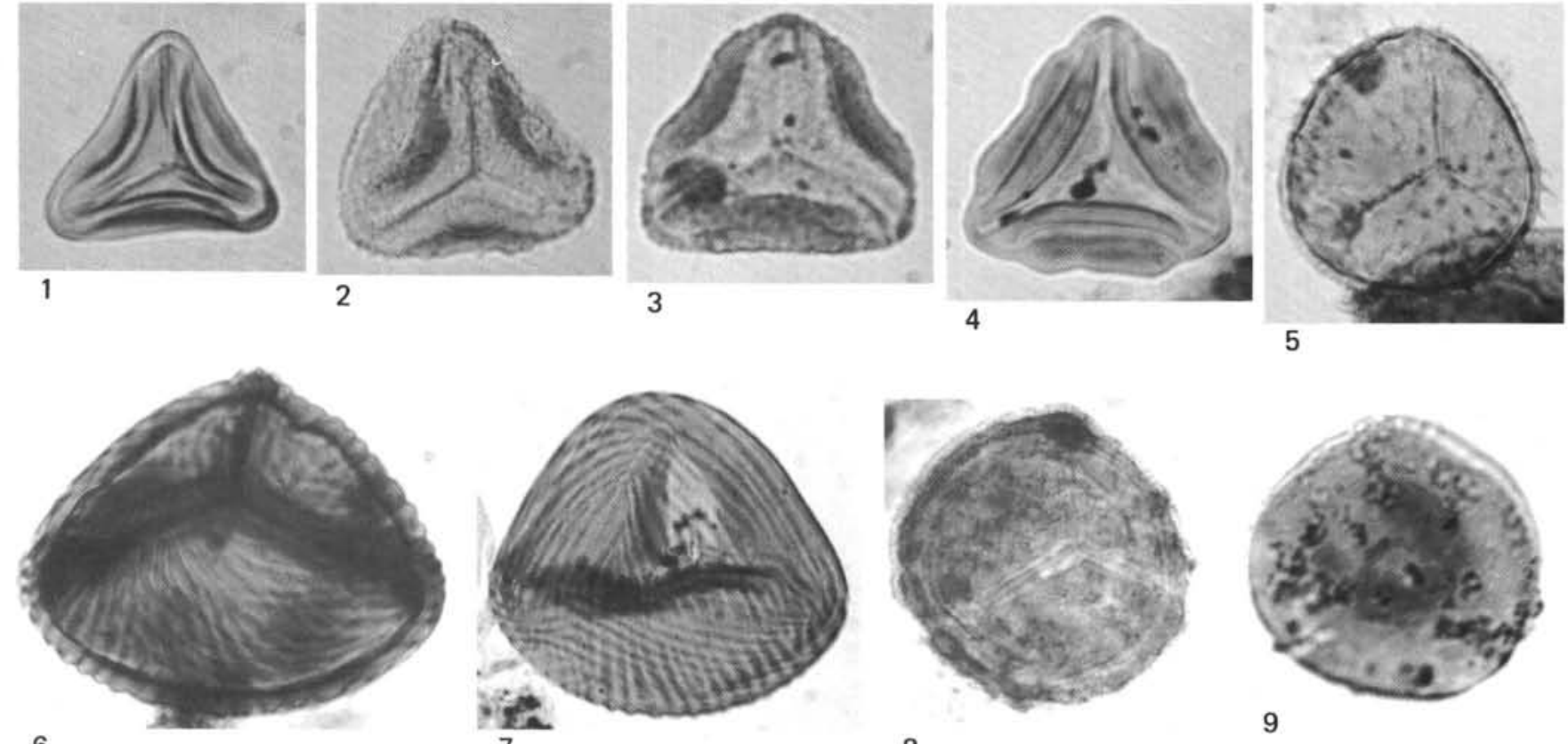

7

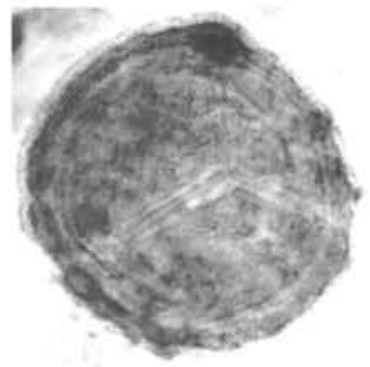

8
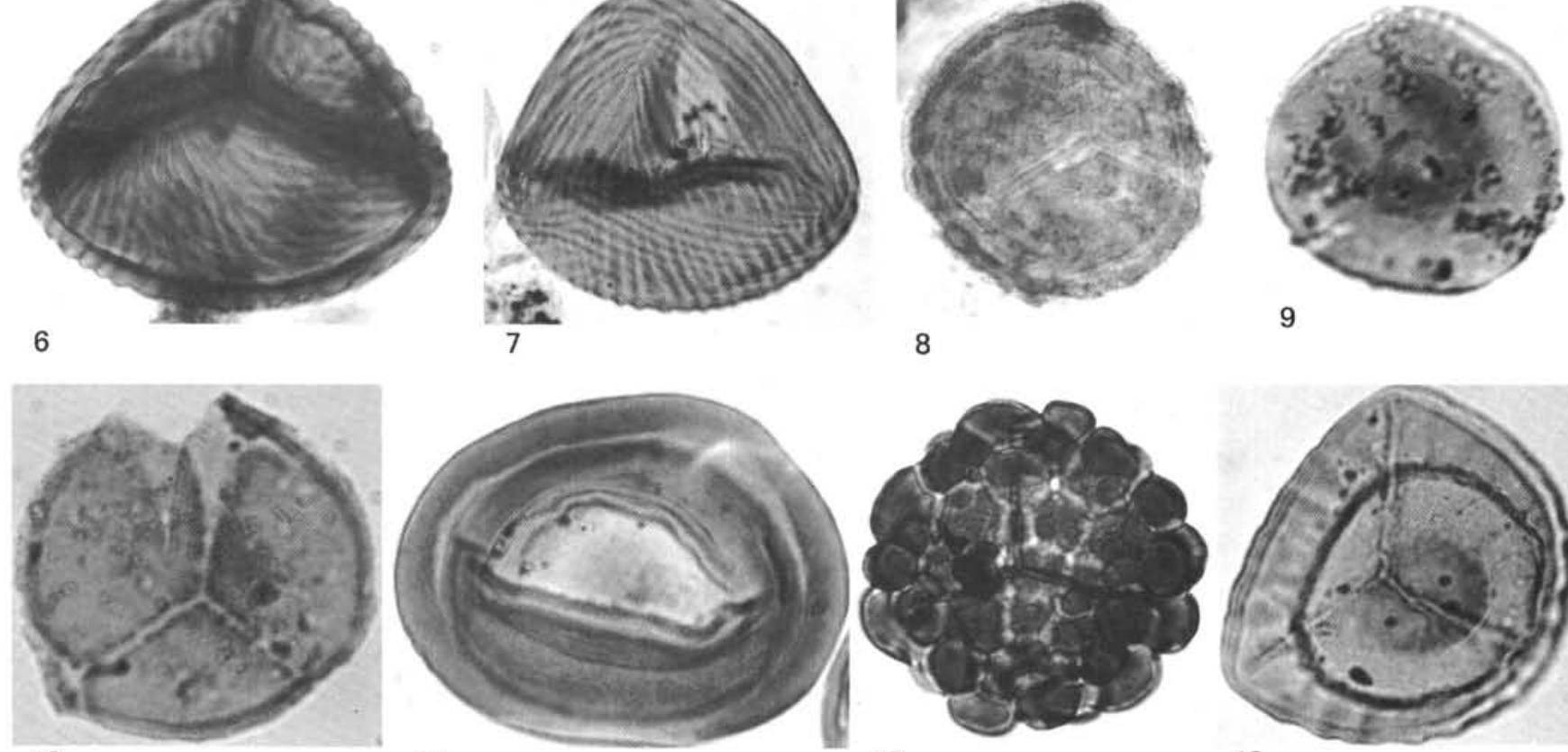

10

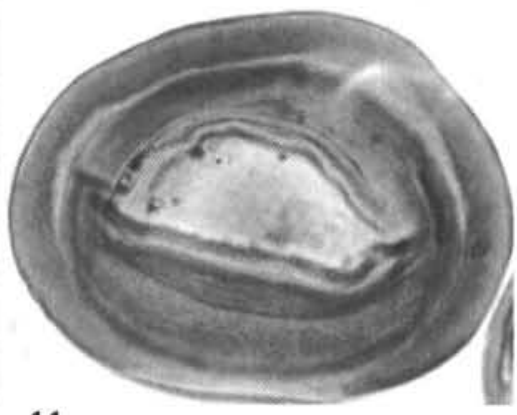

11

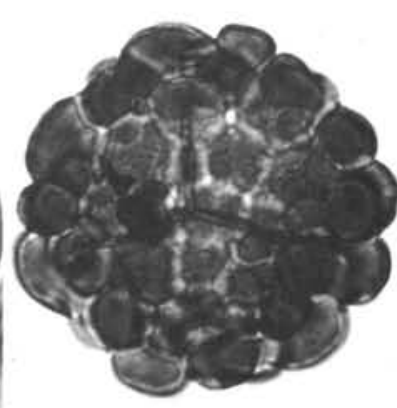

12

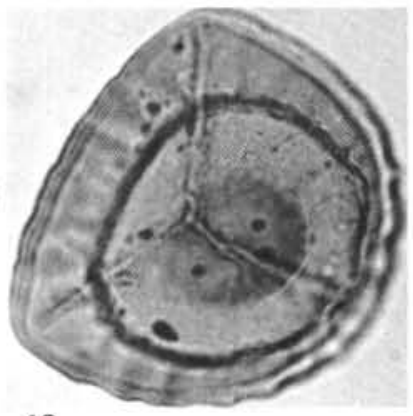

13

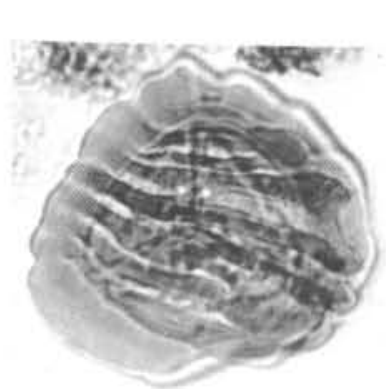

14

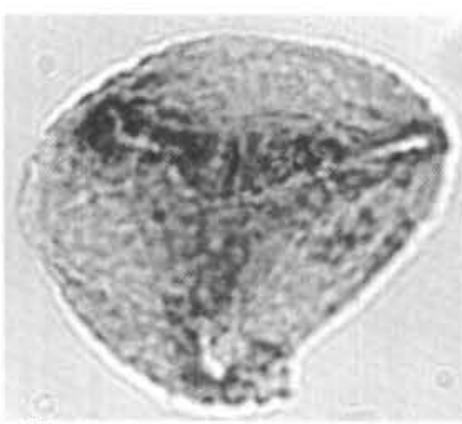

15

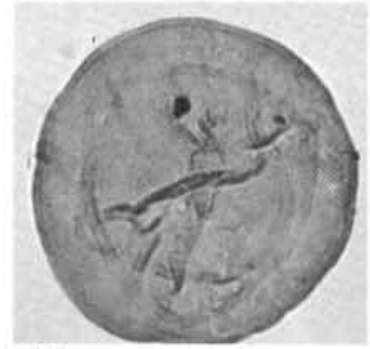

18

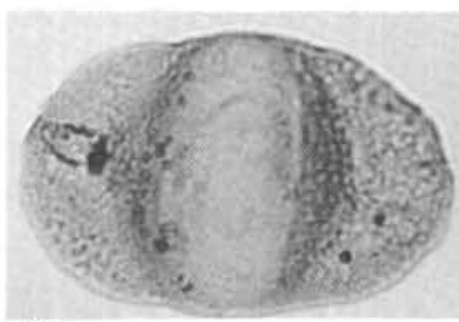

19

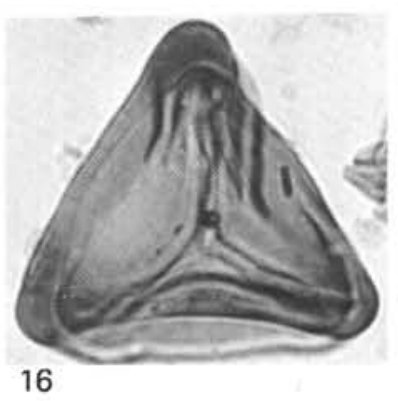

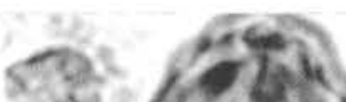

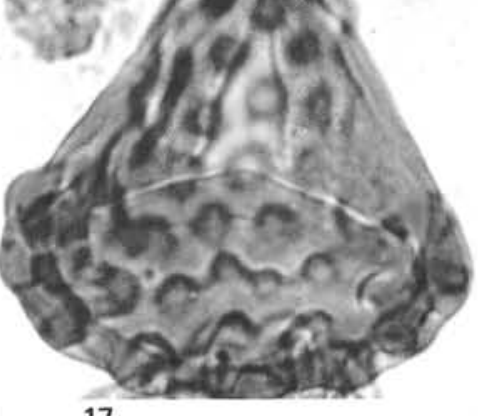

17

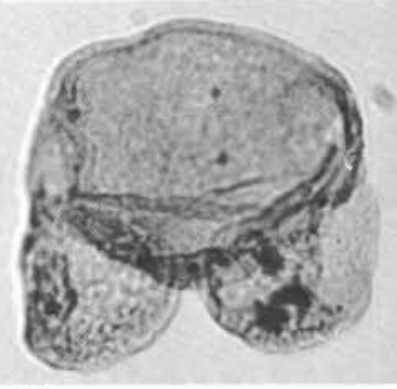

20

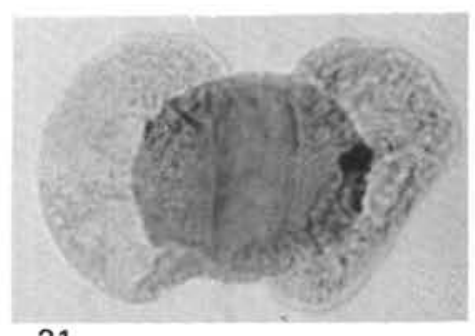

21 


\section{PLATE 2}

Figures 1,2 Gonyaulacysta $\mathrm{sp}$.

Hole $327 \mathrm{~A}(463 \mathrm{~m}), \times$ ca. 650 .

Figure 3 ? Prolixosphaeridium sp.

Hole $327 \mathrm{~A}(463 \mathrm{~m}), \times$ ca. 650 .

Figure 4 Apteodinium cf. A. granulatum Eisenack, 1958.

Hole 327A (426 m), $\times$ ca. 650 .

Figure $5 \quad$ Psaligonyaulax apatela (Cookson and Eisenack) Sarjeant, 1969.

Site $330(315 \mathrm{~m}), \times$ ca. 650 .

Figure $6 \quad$ Meiourogonyaulax sp.

Hole 327A $(463 \mathrm{~m}), \times$ ca. 650 .

Figure 7 Prolixosphaeridium parvispinum (Deflandre) Davey et al., 1969.

Hole 327 A (463 m), X ca. 650 .

Figure $8 \quad$ Cleistosphaeridium sp.

Hole 327 A $(463 \mathrm{~m}), \times$ ca. 650 .

Figure 9 Muderongia mcwhaei Cookson and Eisenack, 1958.

Hole 327A (396 m), $\times$ ca. 650 .

Figure 10 Cyclonephelium distinctum Deflandre and Cookson, 1955.

Hole 327A (396 m), $\times$ ca. 650 .

Figure 11 Cribroperidinium orthoceras (Eisenack) Davey, 1969.

Site $330(271 \mathrm{~m}), \times$ ca. 400 .

Figure 12 Spiniferites cingulatus (O. Wetzel) Sarjeant, 1970. Hole $327 \mathrm{~A}(386 \mathrm{~m}), \times$ ca. 650 .

Figure 13 Oligosphaeridium complex (White) Davey and Williams, 1966.

Hole 327A (426 m), $\times$ ca. 400 . 
PLATE 2

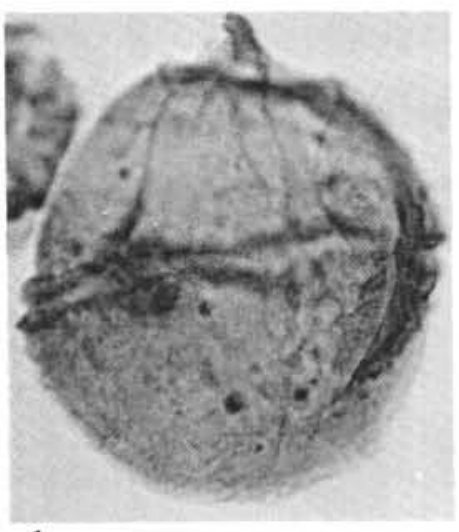

1

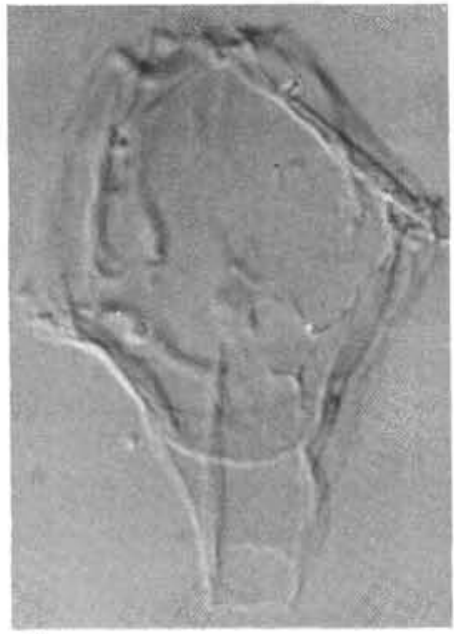

5

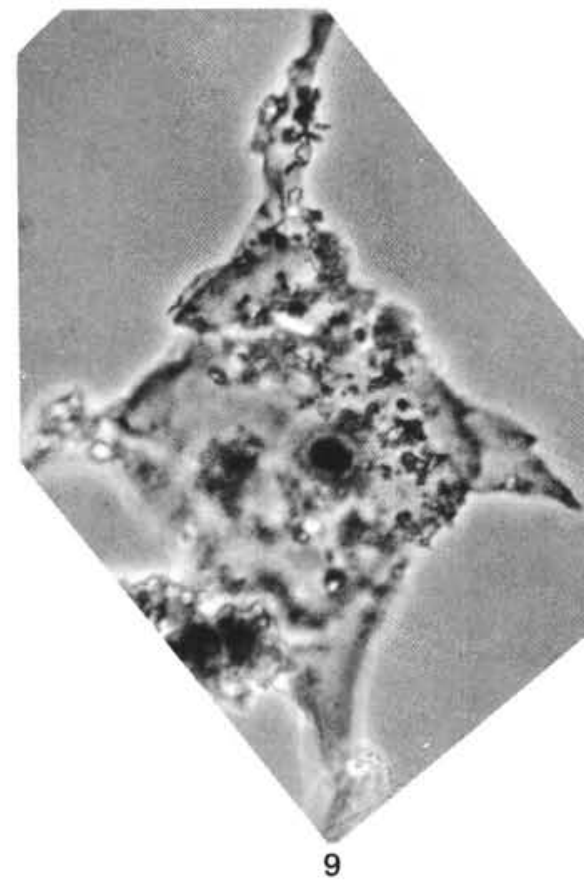

2

6
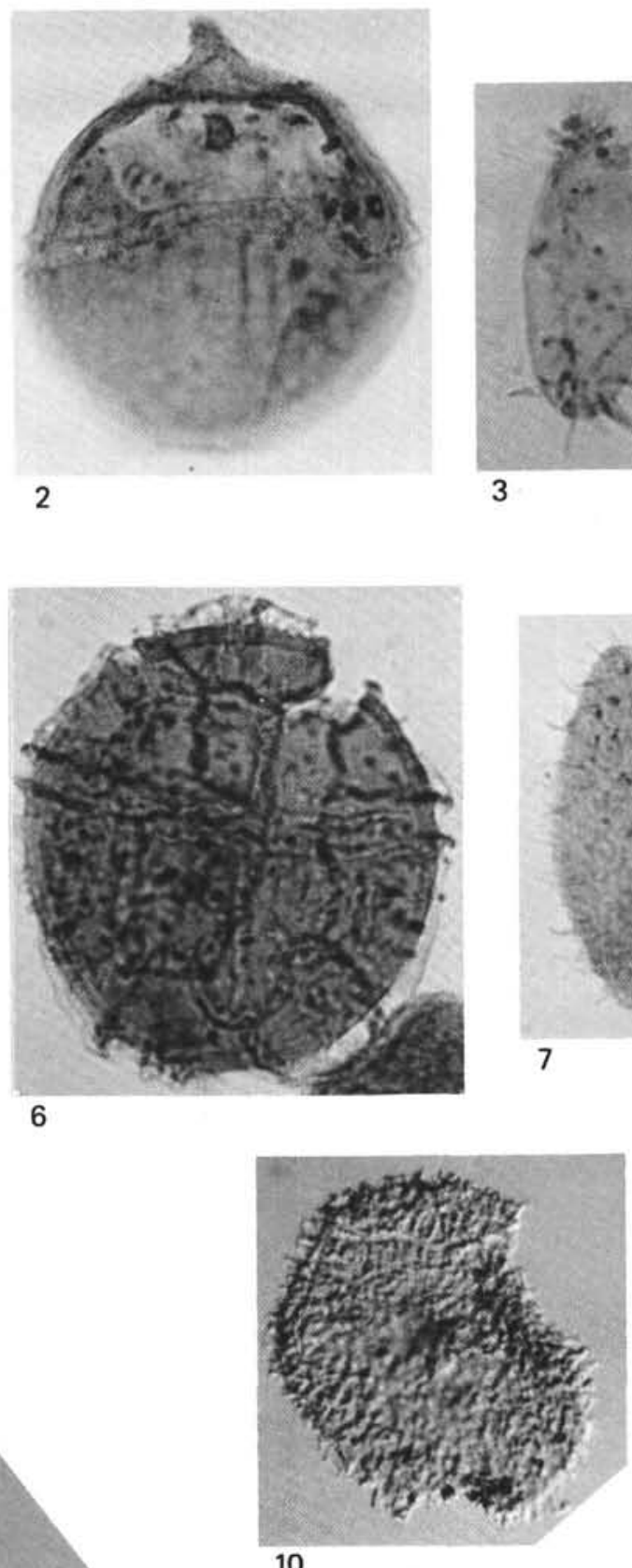

10

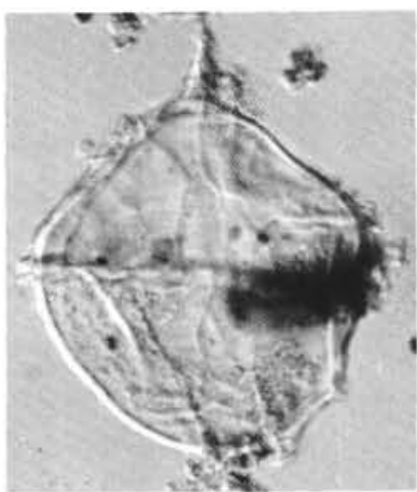

11

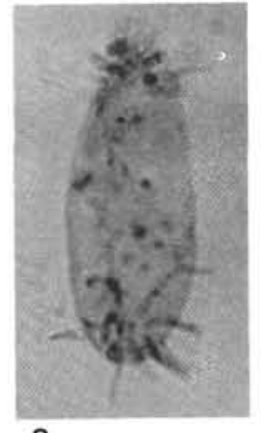

3
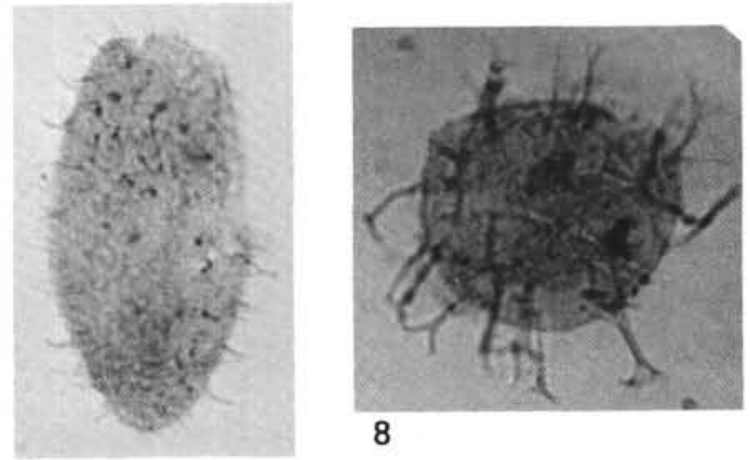

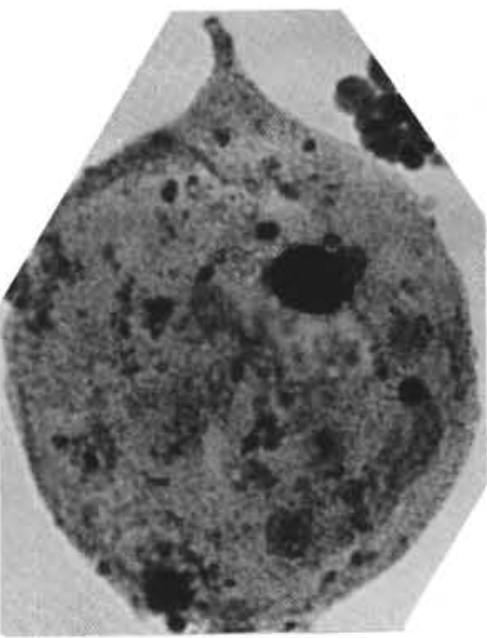

4

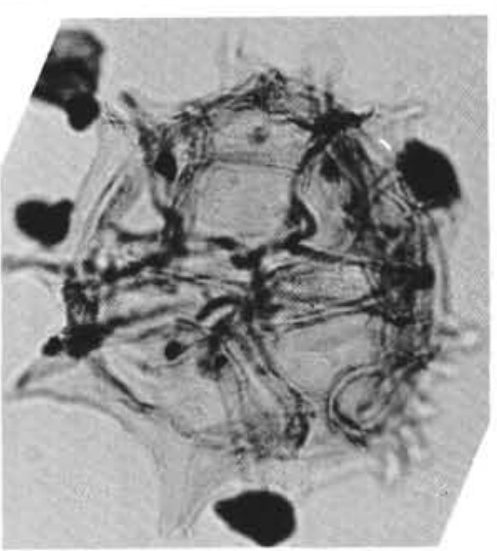

12

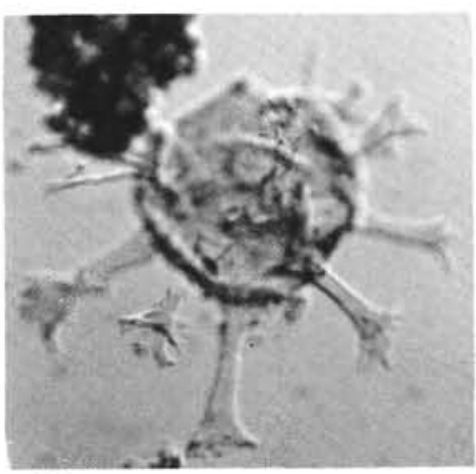

13 


\section{PLATE 3}

Figure 1 Gonyaulacysta jurassica (Deflandre) Norris and Sarjeant, 1965.

Site $330(440 \mathrm{~m}), \times$ ca. 650 .

Figures 2, $3 \quad$ Leptodinium mirabile Klement, 1960.

Site $330(440 \mathrm{~m}), \times$ ca. 400 .

Figure $4 \quad$ Endoscrinium luridum (Deflandre) Gocht, 1970.

Site $330(440 \mathrm{~m}), \times$ ca. 650 .

Figure $5 \quad$ Meiourogonyaulax ghermani Beju, 1971.

Site $330(440 \mathrm{~m}), \times$ ca. 1000 .

Figure 6 Nannoceratopsis pellucida Deflandre, emend. Evitt, 1961.

Site $330(440 \mathrm{~m}), \times$ ca. 650 .

Figure 7 Wallodinium cf. W. glaessneri (Cookson and Eisenack).

Loeblich and Loeblich, 1968.

Site $330(440 \mathrm{~m}), \times$ ca. 650 .

Figure 8 Gonyaulacysta nuciformis (Deflandre) Sarjeant, 1968.

Site $330(440 \mathrm{~m}), \times$ ca. 650 .

Figures 9, $10 \quad$ Systematophora areolata Klement, 1960.

Hole $327 \mathrm{~A}(426 \mathrm{~m}), \times$ ca. 650 .

Figure $11 \quad$ Pareodinia sp.

Site $330(440 \mathrm{~m}), \times$ ca. 650 .

Figure 12 Scriniodinium dictyotum Cookson and Eisenack, 1960.

Site $330(440 \mathrm{~m}), \times$ ca. 650 .

Figures 13, 14 Tasmanites sp.

Site $330(440 \mathrm{~m}), \times$ ca. 650 . 
PLATE 3
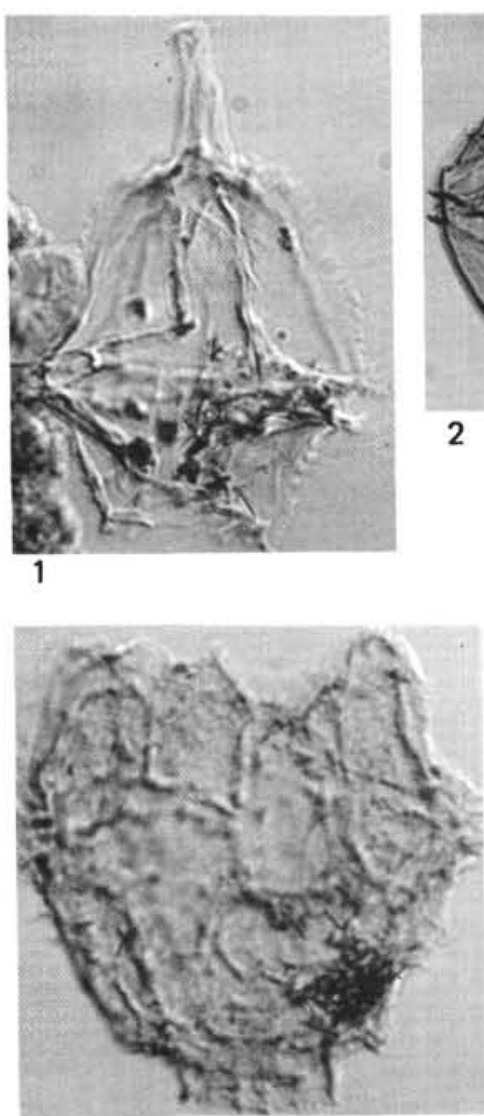

5
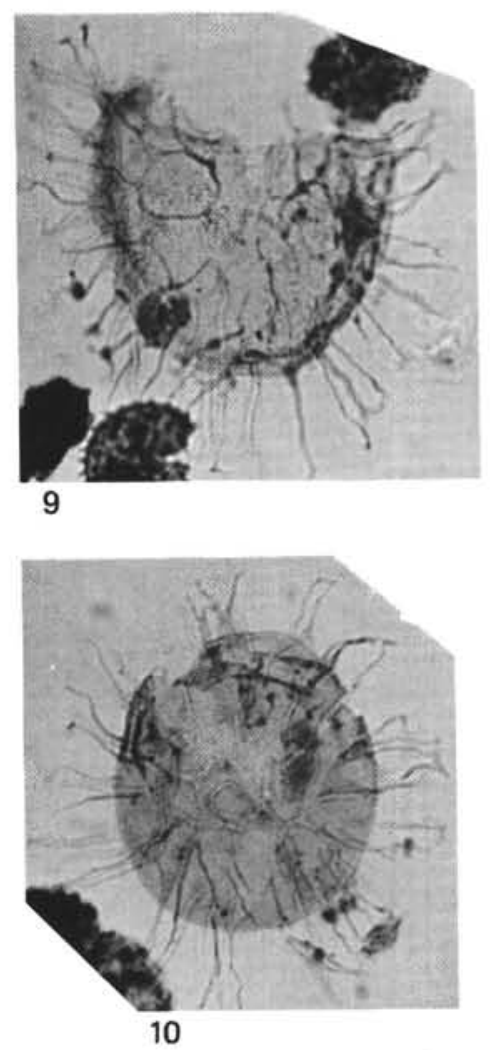

2
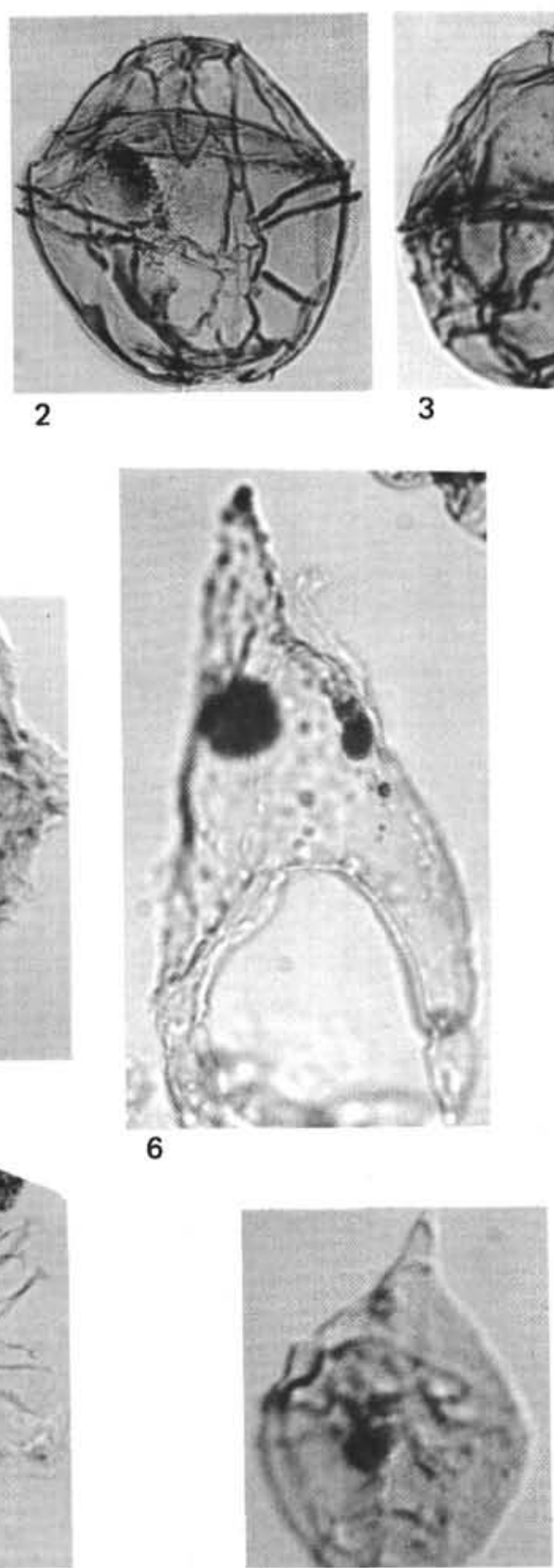

11

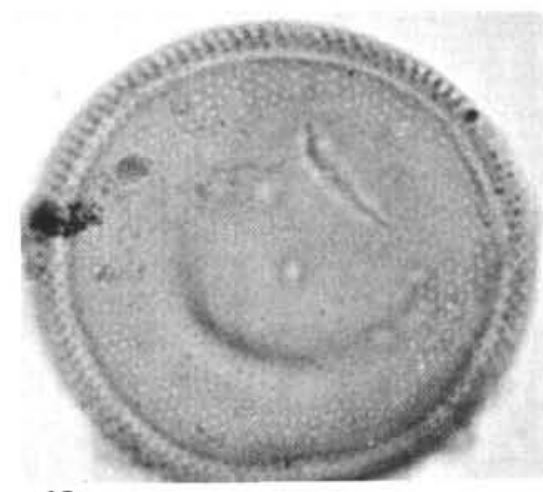

13

3
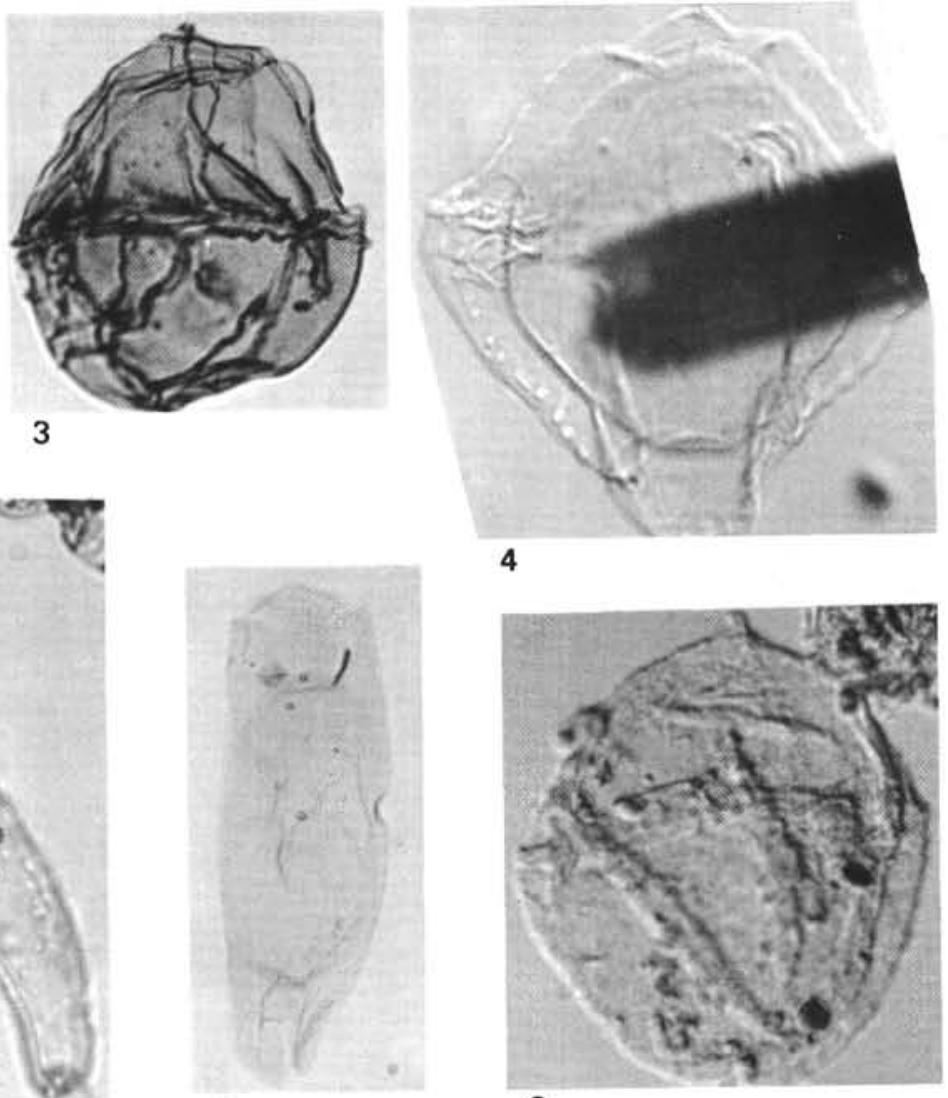

4

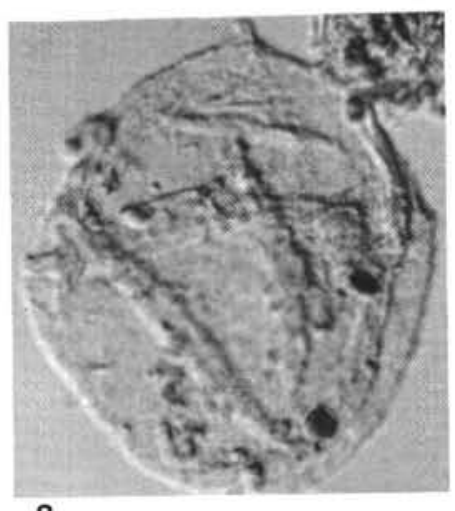

8

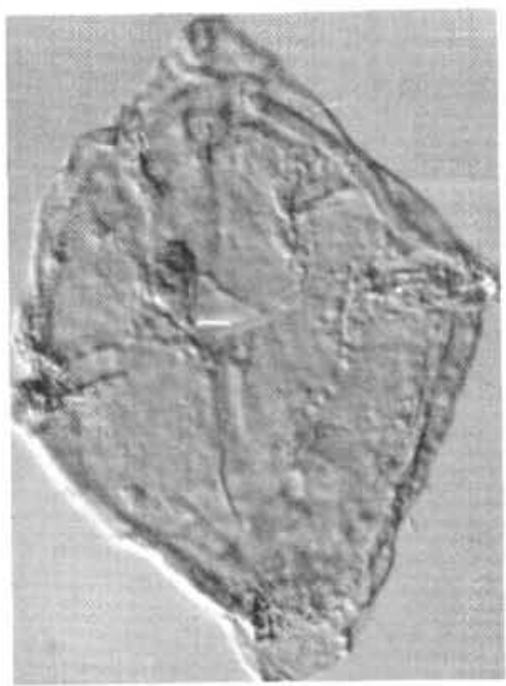

12

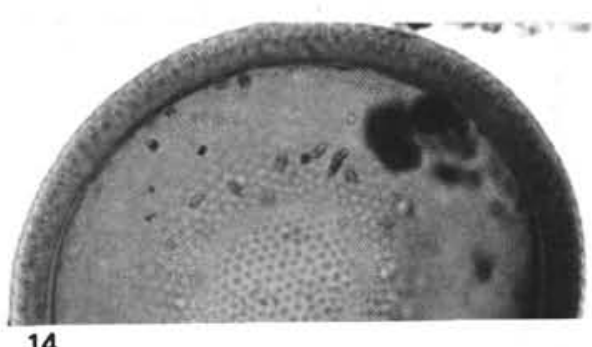

